\title{
Prospero-related homeobox 1 (Prox1) at the crossroads of diverse pathways during adult neural fate specification
}

\author{
Athanasios Stergiopoulos ${ }^{\dagger}$, Maximilianos Elkouris ${ }^{\dagger}$ and Panagiotis K. Politis *
}

Center for Basic Research, Biomedical Research Foundation of the Academy of Athens, Athens, Greece

\section{Edited by:}

Jens Christian Schwamborn,

University of Luxembourg,

Luxembourg

Reviewed by:

Alino Martinez-Marcos, Universidad de Castilla, Spain

Eumorphia Remboutsika, BSRC

Alexander Fleming, Greece

*Correspondence:

Panagiotis K. Politis, Center for Basic Research, Biomedical Research Foundation of the Academy of Athens, 4 Soranou Efesiou Str., 115 27, Athens, Greece e-mail:ppolitis@bioacademy.gr

${ }^{\dagger}$ These authors have contributed equally to this work.
Over the last decades, adult neurogenesis in the central nervous system (CNS) has emerged as a fundamental process underlying physiology and disease. Recent evidence indicates that the homeobox transcription factor Prox 1 is a critical intrinsic regulator of neurogenesis in the embryonic CNS and adult dentate gyrus (DG) of the hippocampus, acting in multiple ways and instructed by extrinsic cues and intrinsic factors. In the embryonic CNS, Prox1 is mechanistically involved in the regulation of proliferation vs. differentiation decisions of neural stem cells (NSCs), promoting cell cycle exit and neuronal differentiation, while inhibiting astrogliogenesis. During the complex differentiation events in adult hippocampal neurogenesis, Prox 1 is required for maintenance of intermediate progenitors (IPs), differentiation and maturation of glutamatergic interneurons, as well as specification of DG cell identity over CA3 pyramidal fate. The mechanism by which Prox1 exerts multiple functions involves distinct signaling pathways currently not fully highlighted. In this mini-review, we thoroughly discuss the Prox1-dependent phenotypes and molecular pathways in adult neurogenesis in relation to different upstream signaling cues and cell fate determinants. In addition, we discuss the possibility that Prox 1 may act as a cross-talk point between diverse signaling cascades to achieve specific outcomes during adult neurogenesis.

Keywords: Prox1, adult neurogenesis, dentate gyrus, hippocampus, neural differentiation, neuronal progenitors, nuclear receptors

\section{INTRODUCTION}

It is now firmly established that active neurogenesis continues throughout life in discrete regions of the central nervous system (CNS) of all mammals, including humans (Eriksson et al., 1998; Temple and Alvarez-Buylla, 1999; Gage, 2000). This revolutionizing finding unraveled the pivotal role of neural stem cells (NSCs) in the adult brain and generated new hope for the treatment of brain impairment during aging and neurodegenerative disorders. Adult neurogenesis is particularly prominent in the subgranular zone (SGZ) of the dentate gyrus (DG) in the hippocampus (Altman and Das, 1965; Seri et al., 2001) and the subventricular zone (SVZ) of the lateral ventricles (Garcia-Verdugo et al., 1998; Johansson et al., 1999). In the hippocampus, an area associated with learning and memory, neurogenesis may play a role in enhancing learning ability, cognitive performance and facilitating the formation of new memories (Deng et al., 2010). The formation of the DG is a complex process that involves cell proliferation, migration and neuronal differentiation (Pleasure et al., 2000). In the SGZ, adult NSCs generate intermediate progenitors (IPs), that eventually differentiate into excitatory glutamatergic granule neurons (Seri et al., 2001). In particular, stem cells with radial processes (radial glia-like cells, type-1 cells) give rise to IPs with high proliferative activity (type-2 cells). A subset of these cells still expresses glial markers, but lack radial processes (type-2a). Another subset, type-2b cells are originating from type- 1 cells as well and show characteristics of neuronal lineage, expressing transcription factors such as Prox1 and NeuroD1 (Steiner et al., 2006). Type-2 cells respond to physiological stimuli such as physical exercise (Kronenberg et al., 2003) or pharmacological stimulation (Encinas et al., 2006), and are prone to differentiate into neuronal committed neuroblasts (type-3 cells). Under normal conditions, type- 3 cells exert little proliferative activity, whereas under experimental seizures mimicking pathological conditions, type-3 cells show increased proliferation (Jessberger et al., 2005). Once they exit cell cycle, newly formed neurons send their axons to target areas such as the CA2 and CA3 of hippocampus, where they form appropriate synapses. The balanced coordination of these processes is essential for tissue homeostasis in the adult brain.

Prox1, a homeobox transcription factor, has been suggested to play key roles in adult neurogenesis of the hippocampus. Interestingly, Prospero, the Drosophila homologue of Prox1 in vertebrates, is a critical regulator of the balance between selfrenewal and differentiation in NSCs (Li and Vaessin, 2000; Choksi et al., 2006). Prospero suppresses the genetic program for selfrenewal of NSCs and cell cycle progression, while it activates genes necessary for terminal neuronal differentiation (Choksi et al., 2006; Southall and Brand, 2009). Neuroblasts that lack Prospero form tumors in the embryonic nervous system of Drosophila (Choksi et al., 2006). In vertebrates, Proxl is a key regulator for the generation of many organs during embryogenesis such as the brain, spinal cord, retina, lens, liver, pancreas and endothelial 

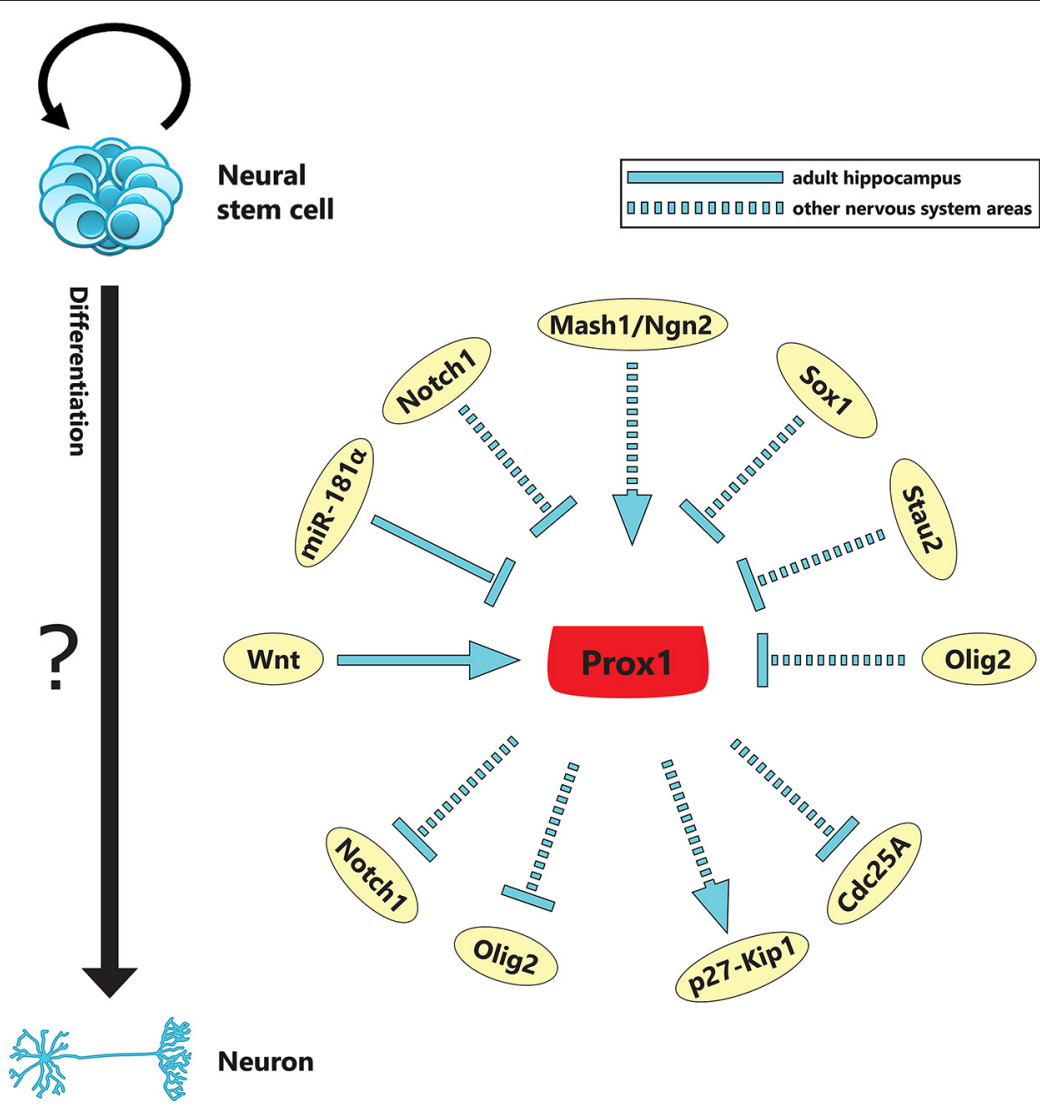

FIGURE 1 | Schematic depiction of the involvement of Prox1 in diverse critical pathways that regulate neurogenesis during adult and embryonic NSC fate specification. Prox 1 may act as a key cross-talk point between upstream and downstream signaling processes to achieve specific outcomes during neurogenesis in the adult DG of the hippocampus (i.e., canonical Wnt,
miR-181 $\alpha$; continuous line) and the embryonic CNS (i.e., Notch1, Mash1/Ngn2 proneural genes, Sox1, Stau2, Olig2; discontinuous line). Furthermore, Prox 1 acts as tumor suppressor gene in neuroblastoma cells by regulating basic components of the cell cycle machinery (i.e., p27-Kip1, Cdc25A) (see also Table 1). lymphatic system (Oliver et al., 1993; Tomarev et al., 1996; Wigle and Oliver, 1999; Wigle et al., 1999; Sosa-Pineda et al., 2000; Dyer et al., 2003; Wang et al., 2005; Lavado and Oliver, 2007; Misra et al., 2008; Kaltezioti et al., 2010). Prox1 knock out embryos die before birth due to multiple developmental defects (Wigle and Oliver, 1999; Wigle et al., 1999). Although the role of Prox1 in the development of lymphatic vasculature, liver, pancreas, heart and lens has received much attention in previous studies (Wigle et al., 1999; Sosa-Pineda et al., 2000; Burke and Oliver, 2002; Risebro et al., 2009), its potential role in neurogenesis has just begun to emerge (Wigle and Oliver, 1999; Wigle et al., 2002; Lavado and Oliver, 2007; Misra et al., 2008; Kaltezioti et al., 2010, 2014; Lavado et al., 2010). Accordingly, we have recently unraveled the key role of Proxl in regulating the fine balance between proliferation and differentiation of NSCs during spinal cord development and neuroblastoma cancer progression (Kaltezioti et al., 2010; Foskolou et al., 2013). In particular, we showed that Prox1 promotes neurogenesis and inhibits astrogliogenesis and self-renewal of embryonic NSCs. We also reported that Proxl suppresses cell cycle progression and proliferation of neuroblastoma cancer cells via a direct action in basic components of the cell cycle machinery (Foskolou et al., 2013).
Moreover, we very recently showed that Proxl controls binary fate decisions between motor neurons and V2 interneurons in the developing spinal cord via direct repression of Olig2 gene expression (Kaltezioti et al., 2014). Collectively, these observations indicate a central role for Prox1 in neural development (Figure 1; Table 1).

\section{PROX1 IS A KEY PLAYER IN HIPPOCAMPAL NEUROGENESIS}

In the brain, Prox1 is detected in various regions, including cortex (CTX), DG, thalamus, hypothalamus and cerebellum during prenatal and postnatal developmental stages and adulthood (Oliver et al., 1993; Galeeva et al., 2007; Lavado and Oliver, 2007). Prox 1 has been proposed to act as a master regulator of hippocampal neurogenesis (Lavado et al., 2010; Karalay and Jessberger, 2011; Karalay et al., 2011; Iwano et al., 2012; Sugiyama et al., 2014). During early stages of hippocampal formation, the DG is generated from NSCs of the dentate neuroepithelium (DNE), a region highly expressing Proxl (Lavado and Oliver, 2007). At later prenatal and postnatal developmental stages, Prox 1 is detected in type-2 IPs (Dcx+, Tbr2+ cells) that reside in the SGZ, in type-2 IPs and early born neurons (NeuroD+ cells) along the dentate migratory stream (DMS) and finally in the 
Table 1 | List of Prox1-dependent phenotypes and molecular pathways implicated in adult and embryonic neural fate specification (see also Figure 1).

\begin{tabular}{|c|c|c|c|}
\hline Nervous tissue & Prox1 Role/Regulation & Organism & References \\
\hline $\begin{array}{l}\text { Dentate Gyrus (DG) } \\
\text { (embryonic \& adult } \\
\text { hippocampus) }\end{array}$ & $\begin{array}{l}\text { Maturation of granule neurons; NSC proliferation and } \\
\text { maintenance; survival of intermediate progenitors (IPS) }\end{array}$ & Mouse & $\begin{array}{l}\text { Lavado and Oliver (2007), Lavado et al. } \\
\text { (2010), Karalay and Jessberger (2011), } \\
\text { Karalay et al. (2011) }\end{array}$ \\
\hline Adult Dentate Gyrus & $\begin{array}{l}\text { Canonical Wnt signaling directly regulates Prox1 } \\
\text { expression; Prox1 induces neuronal differentiation }\end{array}$ & Mouse & $\begin{array}{l}\text { Karalay and Jessberger (2011), Karalay } \\
\text { et al. (2011) }\end{array}$ \\
\hline $\begin{array}{l}\text { Postnatal \& Adult } \\
\text { Hippocampus }\end{array}$ & $\begin{array}{l}\text { Postmitotic specification of DG granule cell identity over } \\
\text { CA3 pyramidal cell fate }\end{array}$ & Mouse & Iwano et al. (2012) \\
\hline Adult Hippocampus & $\begin{array}{l}\text { miR-181 } \alpha \text { overexpression mimics reduced Prox1 levels } \\
\text { and increased Notch1 levels; induction of astrocytic } \\
\text { differentiation }\end{array}$ & Mouse & Xu et al. (2014) \\
\hline Adult Hippocampus & $\begin{array}{l}\text { Robust promotion of DG cell replacement (transplantation } \\
\text { studies) }\end{array}$ & Rat & Chen et al. (2011) \\
\hline $\begin{array}{l}\text { Embryonic Spinal } \\
\text { Cord }\end{array}$ & $\begin{array}{l}\text { Regulation of Notch1-Mediated Inhibition of Neurogene- } \\
\text { sis; induction of neurogenesis; inhibition of astrogliogen- } \\
\text { esis and self-renewal of NSCs }\end{array}$ & $\begin{array}{l}\text { Mouse } \\
\text { Chicken }\end{array}$ & Kaltezioti et al. (2010) \\
\hline Embryonic Spinal & Liver receptor homologue-1 (LRH-1/NR5A2) facilitates the & Mouse & Kaltezioti et al. (2010), Stergiopoulos and \\
\hline Cord & Prox1-mediated inhibition of Notch1 signaling & Chicken & Politis (2013) \\
\hline $\begin{array}{l}\text { Embryonic Spinal } \\
\text { Cord }\end{array}$ & $\begin{array}{l}\text { Regulation of binary fate decisions between motor neu- } \\
\text { rons and V2 interneurons via direct repression of Olig2 } \\
\text { gene expression }\end{array}$ & $\begin{array}{l}\text { Mouse } \\
\text { Chicken }\end{array}$ & Kaltezioti et al. (2014) \\
\hline $\begin{array}{l}\text { Embryonic Central } \\
\text { Nervous System } \\
\text { (CNS) }\end{array}$ & $\begin{array}{l}\text { Mash1 and Ngn2 induce Prox1 expression; reduced Prox1 } \\
\text { levels in Mash1-/- mice }\end{array}$ & $\begin{array}{l}\text { Mouse } \\
\text { Chicken }\end{array}$ & Misra et al. (2008), Torii et al. (1999) \\
\hline $\begin{array}{l}\text { Embryonic } \\
\text { Subventricular Zone } \\
\text { (SVZ) }\end{array}$ & $\begin{array}{l}\text { Sox1 maintains the pool of cortical progenitors by sup- } \\
\text { pressing Prox1-induced neurogenesis }\end{array}$ & Mouse & Elkouris et al. (2011) \\
\hline Embryonic Cortex & $\begin{array}{l}\text { Staufen2 (Stau2)-dependent RNA complex represses } \\
\text { Prox } 1 \text { mRNA; reduced neurogenesis }\end{array}$ & Mouse & Vessey et al. (2012) \\
\hline $\begin{array}{l}\text { Nervous System- } \\
\text { related Cancers }\end{array}$ & $\begin{array}{l}\text { Tumor suppressor gene by regulating Cyclins, p27-Kip1 } \\
\text { and Cdc25A; induction of cell cycle arrest }\end{array}$ & $\begin{array}{l}\text { Mouse } \\
\text { Human }\end{array}$ & Foskolou et al. (2013) \\
\hline $\begin{array}{l}\text { Drosophila Nervous } \\
\text { System (prospero) }\end{array}$ & $\begin{array}{l}\text { Inhibition of the genetic program for NSC self-renewal \& } \\
\text { cell cycle progression; Prox1-/- neuroblasts form tumors } \\
\text { (embryonic nervous system); Activation of genes neces- } \\
\text { sary for terminal neuronal differentiation }\end{array}$ & $\begin{array}{l}\text { Drosophila } \\
\text { melanogaster }\end{array}$ & $\begin{array}{l}\text { Li and Vaessin (2000), } \\
\text { Choksi et al. (2006), } \\
\text { Southall and Brand (2009) }\end{array}$ \\
\hline
\end{tabular}

mature granule cells (calbindin+) that mainly compose the adult DG (Lavado et al., 2010; Iwano et al., 2012; Sugiyama et al., 2014). Therefore, it is commonly used as a specific marker for the DG cell lineage (Oliver et al., 1993; Galeeva et al., 2007; Lavado and Oliver, 2007). Most importantly, recent in vivo data support the notion that Proxl is necessary for IP maintenance and survival as well as granule neuron differentiation and maturation in embryonic and adult hippocampus (Lavado et al., 2010; Karalay and Jessberger, 2011; Karalay et al., 2011; Iwano et al., 2012; Table 1). Interestingly, Proxl-expressing IPs are required for adult NSC self-maintenance in the DG through a non-cell autonomous regulatory feedback mechanism (Lavado et al., 2010). Moreover, Prox1 postmitotically specifies DG granule cell identity over CA3 pyramidal cell fate in the early postnatal and adult hippocampus (Lavado and Oliver, 2007; Iwano et al., 2012). In addition, transplantation studies have shown that only donor cells expressing Proxl can promote robust DG cell replacement in the adult rat hippocampus highlighting the critical role of Proxl in adult DG neurogenesis (Chen et al., 2011).
Apparently, all Prox1 functions in the developing and adult hippocampus cannot be explained by one control mechanism. The temporal and spatial expression of Prox1 suggests a complex regulatory mode of action in a cell-context manner. The mechanism by which Proxl exerts multiple functions involves distinct signaling pathways currently not fully understood. In the adult DG, Prox1-expressing precursor cells respond to several stimuli, such as growth factors (Lee and Agoston, 2010), physical activity, enriched environments and kainic-acid induced seizures, which contribute to neuronal regeneration and plasticity (Steiner et al., 2008). Most importantly, Proxl is sufficient to direct the differentiation of progenitor cells into mature neurons in vivo. Niche-derived signals that determine cell fate and ensure life-long neurogenesis in the adult mammalian DG are recently linked to Prox1. In particular, canonical Wnt signaling emanated by hippocampal astrocytes has been shown to promote ectopic Proxl activation by direct binding of $\beta$-catenin on the Prox1 TCF/LEF enhancer sites, hence triggering Prox1-mediated neuronal differentiation (Karalay and Jessberger, 2011; Karalay et al., 2011). Furthermore, recent 
evidence highlighted the important role of microRNAs in the regulation of Prox 1 activity. In particular, miR-181a has been shown to directly bind to the 3'UTR Proxl sequence while its overexpression mimics reduced Prox1 levels, and ultimately drives adult hippocampal progenitors into an astrocytic fate (Kazenwadel et al., 2010; Xu et al., 2014; Figure 1). However, the cell-autonomous transcription program that is activated by Prox 1 in adult NSCs to instructively direct neuronal differentiation is still elusive.

\section{INSIGHTS FOR PROX1 MOLECULAR FUNCTION IN THE ADULT HIPPOCAMPUS FROM OTHER AREAS OF THE NERVOUS SYSTEM}

The identification of Proxl downstream targets that control NSC maintenance and differentiation is of cardinal importance in order to delineate the stage and time specific role of Prox 1 in adult hippocampal neurogenesis. Towards this aim, functional evidence suggests that Prox1 counteracts Notch1 signaling via direct suppression of Notch1 gene expression to promote neurogenesis and inhibit astrogliogenesis and self-renewal of NSCs in the developing spinal cord (Kaltezioti et al., 2010). Considering the important role of Notch1 in promoting maintenance of NSCs during adult-SGZ neurogenesis (Ables et al., 2010; Ehm et al., 2010; Lugert et al., 2010), we could hypothesize that Prox1 may affect adult neuronal progenitors by directly regulating Notch1 signaling. In adult hippocampal neural progenitor cells, decreased Proxl levels by miR-181a overexpression was accompanied by increased Notch1 levels further providing evidence for the mechanistic association of these factors (Xu et al., 2014). Moreover, we recently showed that Prox 1 acts as tumor suppressor gene in nervous system related cancers by regulating basic components of the cell cycle machinery, including Cyclins, p27-Kip1 and Cdc25A, to induce cell cycle arrest (Foskolou et al., 2013). This anti-proliferative action of Prox 1 could also be involved in the exit of adult NSCs from the cell cycle and induction of terminal neuronal differentiation of the adult-SGZ-derived neurons (Figure 1; Table 1).

Evidence from the embryonic brain on Prox1 regulation and activity might as well provide useful information towards the discovery of novel cellular and molecular mechanisms involved in adult hippocampal neurogenesis. Critical pathways that maintain the balance between NSC maintenance and differentiation, including Notch, Sox and proneural factors, have been linked to Proxl activity (Torii et al., 1999; Misra et al., 2008; Kaltezioti et al., 2010; Elkouris et al., 2011). The SoxB1 subfamily (Sox1-3) is expressed by NSCs and IPs in the developing nervous system, where these factors maintain these cells in an undifferentiated state while suppressing neuronal differentiation (Remboutsika et al., 2011; Mandalos et al., 2012, 2014; Karnavas et al., 2013). One mechanism is mediated by Sox 1 that maintains the pool of cortical progenitor cells by suppressing Prox1-induced neurogenesis in the mammalian embryonic SVZ (Elkouris et al., 2011). All SoxB1 transcription factors (Sox1-3) mark both radial astrocytes (type 1 cells) and early progenitor cells (type 2 a cells) within the adult DG providing evidence for their potential implication in Prox1 regulation (Steiner et al., 2006; Wang et al., 2006; Venere et al., 2012). Sox21, another member of the $\operatorname{SoxB}$ genes, is also a critical regulator of adult neurogenesis in mouse hippocampus. Loss of Sox 21 impairs transition of progenitor cells from type $2 \mathrm{a}$ to type $2 \mathrm{~b}$, thereby reducing subsequent production of new neurons in the adult DG (Matsuda et al., 2012). Mechanistically, Sox 21 represses expression of the Notch-responsive gene Hes5 at the transcriptional level (Matsuda et al., 2012). Prox1 may possibly play a major role at the point where the Notch and Sox pathways intersect to control neurogenesis in the adult hippocampus.

In addition, Proxl in the embryonic CNS is induced by proneural genes and is required for implementation of their neurogenic program (Torii et al., 1999; Misra et al., 2008). In particular, Prox1 is partially co-expressed with Mash1 and Ngn2 in the SVZ of murine brain and chick spinal cord during the initial stages of neurogenesis. Overexpression of these factors is sufficient to induce Prox1 expression (Torii et al., 1999; Misra et al., 2008). Conversely, Proxl levels are reduced in the embryonic brain of Mash1 knockout mice (Torii et al., 1999), further suggesting that Prox1 expression during neurogenesis is dependent on proneural genes. The epistatic relationship between proneural genes and Prox 1 may also be in action during adult neurogenesis and participate in mediating the important roles of these genes in hippocampal neurogenesis. Recently, another level of complexity in Proxl activity throughout the embryonic brain has been added by RNA binding proteins that control Prox 1 mRNA stability. Staufen2 (Stau2)-dependent RNA complex is essential for appropriate precursor cell maintenance in embryonic cortical progenitor cells by binding and repressing Prox 1 mRNA (Vessey et al., 2012). In this study, genetic knockdown of Stau2 causes enhanced expression of Prox 1 mRNA and subsequently leads to inappropriate neurogenesis, which could be potentially related to adult hippocampal neurogenesis (Figure 1; Table 1).

\section{LESSONS ON PROX1 FUNCTION FROM OTHER NON-NEURAL TISSUES}

In other tissues, additional signaling factors, including HIF$1 \alpha /$ HIF- $2 \alpha$, LSD 1 and Nuclear receptors (COUP-TFII, LRH1, RORs), directly or indirectly affect Prox1 expression or activity (Table 2). Many of these factors are also key players in neural cell fate decisions raising the intriguing possibility that these factors may contribute to Proxl mode of action in neurogenesis during development and adulthood. As an example, during lymphatic development, COUP-TFII (chicken ovalbumin upstream promoter-transcription factor II/NR2F2), a transcription factor also related to neuronal development, specifies lymphatic endothelial identity by physically and functionally interacting with Proxl and specifically by forming heterodimers with Prox 1 thereby maintaining the expression of FGFR-3 and VEGFR-3 genes and leading to the repression of the Notch target genes Hey1/2 (Lee et al., 2009; Yamazaki et al., 2009; Aranguren et al., 2013). Moreover, COUP-TFII is necessary for the initiation and early maintenance of Prox 1 expression during specification and differentiation of lymphatic endothelial cells (Srinivasan et al., 2010). Interestingly, apart from being expressed in Proxl positive cells in the ganglionic eminences and in migrating cortical interneurons during forebrain 
development (Kanatani et al., 2008; Lin et al., 2011; Cai et al., 2013; Rubin and Kessaris, 2013), COUP-TFII is also detected in restricted populations of glutamatergic pyramidal cells and GABAergic neurons in the adult rat hippocampus (Fuentealba et al., 2010). This cell type-specific role of COUP-TFII could suggest potential correlation and/or interaction with Prox 1 in cell fate decisions and neuronal maturation during adult hippocampal neurogenesis.

Proxl has also been identified as a co-repressor partner for liver receptor homologue-1 (LRH-1/NR5A2), a critical regulator of liver and pancreas development. The overlapping expression patterns and the direct interaction of these two transcription factors led to the identification of novel molecular mechanisms via which Proxl and LRH-1 co-ordinately regulate the characteristics of hepatocytes (Qin et al., 2004, 2009; Steffensen et al., 2004; Kamiya et al., 2008; Stein et al., 2014). These findings propose important functions of Proxl and LRH-1 complex during development of the enterohepatic system and in adult physiology of the liver. Most importantly, LRH-1 mRNA levels have also been detected in the brain of adult mice (Grgurevic et al., 2005; Gofflot et al., 2007). LRH-1 seems to have significant and specific roles in CNS development among other tissues. Recently, we showed that this orphan nuclear receptor is expressed in the developing spinal cord and facilitates the Prox1-mediated inhibition of Notch1 signaling (Kaltezioti et al., 2010; Stergiopoulos and Politis, 2013). It would also be interesting to further examine whether LRH-1 continues to contribute to Prox 1 mode of action during adult neurogenesis in the hippocampus.

Other examples of factors that regulate Prox 1 expression are the hypoxia-inducible factors $1 \alpha$ and $2 \alpha$ (HIF- $1 \alpha / \mathrm{HIF}-2 \alpha$ ). HIF$1 \alpha$ or HIF- $2 \alpha$ can directly interact with the hypoxia-response element (HRE) at the Prox 1 promoter and induce Proxl expression in response to hypoxia (Zhou et al., 2013). In addition, Prox 1 promotes hepatocellular carcinoma metastasis by inducing the expression and protein stability of HIF-1 $\alpha$ (Liu et al., 2013). In the brain, HIF-1 $\alpha$ has been shown to be involved in neurological symptoms of cerebral ischemia. For example, inhibition of HIF- $1 \alpha$ and its downstream genes lead to amelioration of the symptoms and neurological deficits in a rat model of focal cerebral ischemia (Chen et al., 2010). HIF- $1 \alpha$ elimination is also neuroprotective in neonatal hypoxicischemic injury (Chen et al., 2008). Moreover, HIF-1 $\alpha$ ameliorates and reduces neuronal apoptosis in a rat model for spinal cord injury (SCI) (Chen et al., 2013). At last, it was recently reported that up-regulation of HIF- $1 \alpha$ expression in NSCs or olfactory ensheathing cells (OECs), used in transplantations for the repair of CNS injury, enabled these cells to more efficiently differentiate towards the neuronal lineage (Wang et al., 2014). All these observations could propose potential synergistic roles for HIF- $1 \alpha /$ HIF- $2 \alpha$ and Prox1 in regulating NSC differentiation during adult neural fate specification and neurological disease progression.

Additionally, in hepatocytes, Prox1 has been shown to interact with LSD1 (lysine-specific demethylase 1) and cause the recruitment of the repressive LSD1/NuRD complex to specific loci, which leads to the co-repression of transcription through epigenetic mechanisms (Ouyang et al., 2013). Regarding its role in nervous system function, LSD1 is involved in the epigenetic control of the initiation of neuronal differentiation program (Ceballos-Chavez et al., 2012; Fuentes et al., 2012; Han et al., 2014). The delineation of the exact role of LSD1/Prox1 complex in the adult brain as well as the identification of potential cell populations that co-express both Prox1 and LSD1 may provide novel insights into the mechanisms involved in adult NSC fate determination.

Finally, Prox1 has also been reported to function as a novel modulator of retinoic acid-related orphan receptors (RORs) $\alpha$ and $\gamma$-mediated transactivation. In particular, Proxl acts as a co-repressor and negatively influences the ROR-mediated regulation of circadian clock and various metabolic networks/pathways (Takeda and Jetten, 2013). Although the role of RORs in nervous system is still unclear, RORs have been linked with important functions in cerebellar development and circadian rhythm (regulation of clock genes) (Jetten, 2009). Further studies towards the understanding of the exact role of RORs in CNS will provide new insights into a potential tissue-specific connection and interaction with Prox1. These nuclear receptors may contribute to Proxl mode of action during adult neurogenesis, since single-nucleotide polymorphisms in RORs have been correlated with increased risk of several psychiatric conditions, including bipolar disorder (Le-Niculescu et al., 2009; Table 2).

\section{PERSPECTIVES}

Important pieces to our understanding of molecular and cellular mechanisms of Prox1-mediated regulation of adult neurogenesis have been added the last years, supporting the notion that Prox1 represents a central node in the cell fate machinery of adult hippocampus. Recently, Wnt signaling has been shown to directly regulate Proxl expression in adult hippocampal neurogenesis. Knowledge from other neural areas during development suggests that additional upstream pathways, including Notch signaling, proneural genes (Neurog2 and Mash1) as well as Sox proteins, might be important factors for Prox1 regulation during adult hippocampal neurogenesis (Figure 1). In addition, studies towards factors implicated in Proxl activity in non-neural tissues, including HIF- $1 \alpha / \mathrm{HIF}-2 \alpha$, LSD1 and Nuclear receptors such as COUP-TFII, LRH-1 and RORs, suggest that these factors should also be evaluated in adult hippocampal neurogenesis. Therefore, further effort must be invested on identifying novel Prox1 regulators and ultimately connect the variety of inputs that affect Proxl levels on the different set of hippocampal cells in the adult DG. Additional complication is likely to be achieved by RNA proteins (Staufen), microRNAs (miR-181 $\alpha$ ) and potentially by lncRNAs (Antoniou et al., 2014) that might be proved important players to fine tune Proxl activity in cell fate decisions of hippocampal cells during adult neurogenesis.

The pleiotropic actions of Prox 1 could be plausibly explained by multiple Proxl targets. Insights from the embryonic brain and other organs suggest that key cell fate regulators, such as Notch, Olig2, p27-Kip1, Cdc25A and HIF- $1 \alpha / 2 \alpha$, could also represent 
Table 2 | Selected list of Prox1 regulatory roles in non-neural cells*.

\begin{tabular}{|c|c|c|c|}
\hline Non-nervous tissues & Prox1 Role/Regulation & Organism & References \\
\hline Enterohepatic & Co-repressor partner for LRH-1; overlapping expression patterns; & Mouse & Qin et al. (2004), Steffensen \\
\hline System & $\begin{array}{l}\text { Prox1 and LRH-1 coordinately regulate the characteristics of } \\
\text { hepatocytes }\end{array}$ & Human & $\begin{array}{l}\text { et al. (2004), Kamiya et al. } \\
\text { (2008), Qin et al. (2009), } \\
\text { Stein et al. (2014) }\end{array}$ \\
\hline Hepatocytes & $\begin{array}{l}\text { Interaction with LSD1 (lysine-specific demethylase 1) and recruit- } \\
\text { ment of the repressive LSD1/NuRD complex to specific loci; co- } \\
\text { repression of transcription via epigenetic mechanisms }\end{array}$ & $\begin{array}{l}\text { Mouse } \\
\text { Human }\end{array}$ & Ouyang et al. (2013) \\
\hline Liver & $\begin{array}{l}\text { Co-repressor of the retinoic acid-related orphan receptors, } \mathrm{ROR} \alpha \\
\text { and ROR } \gamma \text {; negative regulation of circadian clock and metabolic } \\
\text { networks }\end{array}$ & $\begin{array}{l}\text { Mouse } \\
\text { Human }\end{array}$ & $\begin{array}{l}\text { Takeda and Jetten (2013), } \\
\text { Jetten (2009) }\end{array}$ \\
\hline Vascular Endothelium & $\begin{array}{l}\text { miR-181 } \alpha \text { directly binds to the } 3^{\prime} U T R \text { Prox } 1 \text { sequence; negative } \\
\text { regulation of Prox } 1 \text { expression }\end{array}$ & Mouse & Kazenwadel et al. (2010) \\
\hline Lymphatic & Specification of lymphatic endothelial identity by forming & Mouse & Lee et al. (2009), Yamazaki \\
\hline Endothelium & heterodimers with COUP-TFII (NR2F2) & Human & $\begin{array}{l}\text { et al. (2009), Aranguren et al. } \\
\text { (2013), Srinivasan et al. (2010) }\end{array}$ \\
\hline $\begin{array}{l}\text { Hepatocellular } \\
\text { Carcinoma }\end{array}$ & $\begin{array}{l}\text { Promotion of metastasis by inducing the expression and protein } \\
\text { stability of HIF-1 } \alpha \text { (hypoxia-inducible factor } 1 \alpha \text { ) }\end{array}$ & Human & Liu et al. (2013) \\
\hline Various Human cells & $\begin{array}{l}\text { HIF- } 1 \alpha \text { or HIF- } 2 \alpha \text { can directly interact with the hypoxia-response } \\
\text { element (HRE) at the Prox } 1 \text { promoter and induce its expression }\end{array}$ & Human & Zhou et al. (2013) \\
\hline
\end{tabular}

*The factors presented here are also involved in neural cell fate decisions.

downstream targets of Prox1 in the adult DG. In summary, we propose that Proxl might act as a cross-talk point between diverse signaling pathways and cell fate determinants to achieve specific outcomes during adult DG neurogenesis.

\section{ACKNOWLEDGMENTS}

We would like to apologize for studies that were not cited due to space limitations. We thank Petros Moustardas, Valeria Kaltezioti, Daphne Antoniou, Elpinickie Ninou and Dimitris Gkikas for helpful discussions and suggestions. This work was supported by ARISTEIA-II (NeuroNetwk, No.4786), IKYDA (Greek Ministry of Education) and Fondation Santé grants to Panagiotis K. Politis.

\section{REFERENCES}

Ables, J. L., Decarolis, N. A., Johnson, M. A., Rivera, P. D., Gao, Z., Cooper, D. C., et al. (2010). Notch1 is required for maintenance of the reservoir of adult hippocampal stem cells. J. Neurosci. 30, 10484-10492. doi: 10.1523/JNEUROSCI. 4721-09.2010.

Altman, J., and Das, G. D. (1965). Autoradiographic and histological evidence of postnatal hippocampal neurogenesis in rats. J. Comp. Neurol. 124, 319-335. doi: 10.1002/cne.901240303

Antoniou, D., Stergiopoulos, A., and Politis, P. K. (2014). Recent advances in the involvement of long non-coding RNAs in neural stem cell biology and brain pathophysiology. Front. Physiol. 5:155. doi: 10.3389/fphys.2014.00155

Aranguren, X. L., Beerens, M., Coppiello, G., Wiese, C., Vandersmissen, I., Lo Nigro, A., et al. (2013). COUP-TFII orchestrates venous and lymphatic endothelial identity by homo- or hetero-dimerisation with PROX1. J. Cell. Sci. 126, 1164-1175. doi: 10.1242/jcs.116293

Burke, Z., and Oliver, G. (2002). Prox1 is an early specific marker for the developing liver and pancreas in the mammalian foregut endoderm. Mech. Dev. 118, 147155. doi: 10.1016/s0925-4773(02)00240-X

Cai, Y., Zhang, Q., Wang, C., Zhang, Y., Ma, T., Zhou, X., et al. (2013). Nuclear receptor COUP-TFII-expressing neocortical interneurons are derived from the medial and lateral/caudal ganglionic eminence and define specific subsets of mature interneurons. J. Comp. Neurol. 521, 479-497. doi: 10.1002/cne.23186

Ceballos-Chavez, M., Rivero, S., Garcia-Gutierrez, P., Rodriguez-Paredes, M., Garcia-Dominguez, M., Bhattacharya, S., et al. (2012). Control of neuronal differentiation by sumoylation of BRAF35, a subunit of the LSD1-CoREST histone demethylase complex. Proc. Natl. Acad. Sci. U S A 109, 8085-8090. doi: 10.1073/pnas.1121522109

Chen, W., Jadhav, V., Tang, J., and Zhang, J. H. (2008). HIF-1 alpha inhibition ameliorates neonatal brain damage after hypoxic-ischemic injury. Acta Neurochir. Suppl. 102, 395-399. doi: 10.1007/978-3-211-85578-2_77

Chen, C., Ostrowski, R. P., Zhou, C., Tang, J., and Zhang, J. H. (2010). Suppression of hypoxia-inducible factor-1alpha and its downstream genes reduces acute hyperglycemia-enhanced hemorrhagic transformation in a rat model of cerebral ischemia. J. Neurosci. Res. 88, 2046-2055. doi: 10.1002/jnr.22361

Chen, M. H., Ren, Q. X., Yang, W. F., Chen, X. L., Lu, C., and Sun, J. (2013). Influences of HIF-lalpha on Bax/Bcl-2 and VEGF expressions in rats with spinal cord injury. Int. J. Clin. Exp. Pathol. 6, 2312-2322.

Chen, X., Tolkovsky, A. M., and Herbert, J. (2011). Cell origin and culture history determine successful integration of neural precursor transplants into the dentate gyrus of the adult rat. PLoS One 6:e17072. doi: 10.1371/journal.pone.0017072

Choksi, S. P., Southall, T. D., Bossing, T., Edoff, K., De Wit, E., Fischer, B. E., et al. (2006). Prospero acts as a binary switch between self-renewal and differentiation in Drosophila neural stem cells. Dev. Cell 11, 775-789. doi: 10.1016/j.devcel. 2006.09.015

Deng, W., Aimone, J. B., and Gage, F. H. (2010). New neurons and new memories: how does adult hippocampal neurogenesis affect learning and memory? Nat. Rev. Neurosci. 11, 339-350. doi: 10.1038/nrn2822

Dyer, M. A., Livesey, F. J., Cepko, C. L., and Oliver, G. (2003). Prox1 function controls progenitor cell proliferation and horizontal cell genesis in the mammalian retina. Nat. Genet. 34, 53-58. doi: 10.1038/ng1144

Ehm, O., Goritz, C., Covic, M., Schaffner, I., Schwarz, T. J., Karaca, E., et al. (2010). RBPJkappa-dependent signaling is essential for long-term maintenance of neural stem cells in the adult hippocampus. J. Neurosci. 30, 13794-13807. doi: 10.1523/jneurosci.1567-10.2010

Elkouris, M., Balaskas, N., Poulou, M., Politis, P. K., Panayiotou, E., Malas, S., et al. (2011). Soxl maintains the undifferentiated state of cortical neural progenitor cells via the suppression of Prox 1-mediated cell cycle exit and neurogenesis. Stem Cells 29, 89-98. doi: 10.1002/stem.554

Encinas, J. M., Vaahtokari, A., and Enikolopov, G. (2006). Fluoxetine targets early progenitor cells in the adult brain. Proc. Natl. Acad. Sci. U S A 103, 8233-8238. doi: 10.1073/pnas.0601992103

Eriksson, P. S., Perfilieva, E., Bjork-Eriksson, T., Alborn, A. M., Nordborg, C., Peterson, D. A., et al. (1998). Neurogenesis in the adult human hippocampus. Nat. Med. 4, 1313-1317. doi: 10.1038/3305 
Foskolou, I. P., Stellas, D., Rozani, I., Lavigne, M. D., and Politis, P. K. (2013). Proxl suppresses the proliferation of neuroblastoma cells via a dual action in p27-Kip1 and Cdc25A. Oncogene 32, 947-960. doi: 10.1038/onc. 2012.129

Fuentealba, P., Klausberger, T., Karayannis, T., Suen, W. Y., Huck, J., Tomioka, R., et al. (2010). Expression of COUP-TFII nuclear receptor in restricted GABAergic neuronal populations in the adult rat hippocampus. J. Neurosci. 30, 1595-1609. doi: 10.1523/JNEUROSCI.4199-09.2010

Fuentes, P., Canovas, J., Berndt, F. A., Noctor, S. C., and Kukuljan, M. (2012). CoREST/LSD1 control the development of pyramidal cortical neurons. Cereb. Cortex 22, 1431-1441. doi: 10.1093/cercor/bhr218

Gage, F. H. (2000). Mammalian neural stem cells. Science 287, 1433-1438. doi: 10. 1126/science.287.5457.1433

Galeeva, A., Treuter, E., Tomarev, S., and Pelto-Huikko, M. (2007). A prosperorelated homeobox gene Prox-1 is expressed during postnatal brain development as well as in the adult rodent brain. Neuroscience 146, 604-616. doi: 10.1016/j. neuroscience.2007.02.002

Garcia-Verdugo, J. M., Doetsch, F., Wichterle, H., Lim, D. A., and Alvarez-Buylla, A. (1998). Architecture and cell types of the adult subventricular zone: in search of the stem cells. J. Neurobiol. 36, 234-248. doi: 10.1002/(sici)10974695(199808)36:2<234::aid-neu10>3.0.co;2-e

Gofflot, F., Chartoire, N., Vasseur, L., Heikkinen, S., Dembele, D., Le Merrer, J., et al. (2007). Systematic gene expression mapping clusters nuclear receptors according to their function in the brain. Cell 131, 405-418. doi: 10.1016/j.cell. 2007.09.012

Grgurevic, N., Tobet, S., and Majdic, G. (2005). Widespread expression of liver receptor homolog 1 in mouse brain. Neuro. Endocrinol. Lett. 26, 541-547.

Han, X., Gui, B., Xiong, C., Zhao, L., Liang, J., Sun, L., et al. (2014). Destabilizing LSD 1 by Jade- 2 promotes neurogenesis: an antibraking system in neural development. Mol. Cell 55, 482-494. doi: 10.1016/j.molcel.2014.06.006

Iwano, T., Masuda, A., Kiyonari, H., Enomoto, H., and Matsuzaki, F. (2012). Prox1 postmitotically defines dentate gyrus cells by specifying granule cell identity over CA3 pyramidal cell fate in the hippocampus. Development 139, 3051-3062. doi: 10.1242/dev.080002

Jessberger, S., Romer, B., Babu, H., and Kempermann, G. (2005). Seizures induce proliferation and dispersion of doublecortin-positive hippocampal progenitor cells. Exp. Neurol. 196, 342-351. doi: 10.1016/j.expneurol.2005. 08.010

Jetten, A. M. (2009). Retinoid-related orphan receptors (RORs): critical roles in development, immunity, circadian rhythm and cellular metabolism. Nucl. Recept. Signal. 7:e003. doi: 10.1621/nrs.07003

Johansson, C. B., Momma, S., Clarke, D. L., Risling, M., Lendahl, U., and Frisen, J. (1999). Identification of a neural stem cell in the adult mammalian central nervous system. Cell 96, 25-34. doi: 10.1016/s0092-8674(00)80956-3

Kaltezioti, V., Antoniou, D., Stergiopoulos, A., Rozani, I., Rohrer, H., and Politis, P. K. (2014). Prox1 regulates olig2 expression to modulate binary fate decisions in spinal cord neurons. J. Neurosci. 34, 15816-15831. doi: 10.1523/jneurosci. 1865-14.2014

Kaltezioti, V., Kouroupi, G., Oikonomaki, M., Mantouvalou, E., Stergiopoulos, A., Charonis, A., et al. (2010). Prox1 regulates the notch1-mediated inhibition of neurogenesis. PLoS Biol. 8:e1000565. doi: 10.1371/journal.pbio.1000565

Kamiya, A., Kakinuma, S., Onodera, M., Miyajima, A., and Nakauchi, H. (2008). Prospero-related homeobox 1 and liver receptor homolog 1 coordinately regulate long-term proliferation of murine fetal hepatoblasts. Hepatology 48, 252264. doi: 10.1002/hep.22303

Kanatani, S., Yozu, M., Tabata, H., and Nakajima, K. (2008). COUP-TFII is preferentially expressed in the caudal ganglionic eminence and is involved in the caudal migratory stream. J. Neurosci. 28, 13582-13591. doi: 10.1523/jneurosci. 2132-08.2008

Karalay, O., Doberauer, K., Vadodaria, K. C., Knobloch, M., Berti, L., Miquelajauregui, A., et al. (2011). Prospero-related homeobox 1 gene (Proxl) is regulated by canonical Wnt signaling and has a stage-specific role in adult hippocampal neurogenesis. Proc. Natl. Acad. Sci. U S A 108, 5807-5812. doi: 10.1073/pnas. 1013456108

Karalay, O., and Jessberger, S. (2011). Translating niche-derived signals into neurogenesis: the function of Prox1 in the adult hippocampus. Cell Cycle 10, 22392240. doi: $10.4161 /$ cc. 10.14 .15850

Karnavas, T., Mandalos, N., Malas, S., and Remboutsika, E. (2013). SoxB, cell cycle and neurogenesis. Front. Physiol. 4:298. doi: 10.3389/fphys.2013.00298
Kazenwadel, J., Michael, M. Z., and Harvey, N. L. (2010). Proxl expression is negatively regulated by miR-181 in endothelial cells. Blood 116, 2395-2401. doi: 10.1182/blood-2009-12-256297

Kronenberg, G., Reuter, K., Steiner, B., Brandt, M. D., Jessberger, S., Yamaguchi, M., et al. (2003). Subpopulations of proliferating cells of the adult hippocampus respond differently to physiologic neurogenic stimuli. J. Comp. Neurol. 467, 455463. doi: 10.1002/cne.10945

Lavado, A., Lagutin, O. V., Chow, L. M., Baker, S. J., and Oliver, G. (2010). Prox1 is required for granule cell maturation and intermediate progenitor maintenance during brain neurogenesis. PLoS Biol. 8:e1000460. doi: 10.1371/journal.pbio. 1000460

Lavado, A., and Oliver, G. (2007). Proxl expression patterns in the developing and adult murine brain. Dev. Dyn. 236, 518-524. doi: 10.1002/dvdy. 21024

Lee, C., and Agoston, D. V. (2010). Vascular endothelial growth factor is involved in mediating increased de novo hippocampal neurogenesis in response to traumatic brain injury. J. Neurotrauma 27, 541-553. doi: 10.1089/neu.2009.0905

Lee, S., Kang, J., Yoo, J., Ganesan, S. K., Cook, S. C., Aguilar, B., et al. (2009). Proxl physically and functionally interacts with COUP-TFII to specify lymphatic endothelial cell fate. Blood 113, 1856-1859. doi: 10.1182/blood-2008-03145789

Le-Niculescu, H., Patel, S. D., Bhat, M., Kuczenski, R., Faraone, S. V., Tsuang, M. T., et al. (2009). Convergent functional genomics of genome-wide association data for bipolar disorder: comprehensive identification of candidate genes, pathways and mechanisms. Am. J. Med. Genet. B Neuropsychiatr. Genet. 150B, 155-181. doi: 10.1002/ajmg.b.30887

Li, L., and Vaessin, H. (2000). Pan-neural Prospero terminates cell proliferation during Drosophila neurogenesis. Genes Dev. 14, 147-151. doi: 10. 1101/gad.14.2.147

Lin, F. J., Qin, J., Tang, K., Tsai, S. Y., and Tsai, M. J. (2011). Coup d'Etat: an orphan takes control. Endocr. Rev. 32, 404-421. doi: 10.1210/er.2010-0021

Liu, Y., Zhang, J. B., Qin, Y., Wang, W., Wei, L., Teng, Y., et al. (2013). PROX1 promotes hepatocellular carcinoma metastasis by way of up-regulating hypoxiainducible factor lalpha expression and protein stability. Hepatology 58, 692-705. doi: 10.1002/hep. 26398

Lugert, S., Basak, O., Knuckles, P., Haussler, U., Fabel, K., Götz, M., et al. (2010). Quiescent and active hippocampal neural stem cells with distinct morphologies respond selectively to physiological and pathological stimuli and aging. Cell Stem Cell 6, 445-456. doi: 10.1016/j.stem.2010.03.017

Mandalos, N., Rhinn, M., Granchi, Z., Karampelas, I., Mitsiadis, T., Economides, A. N., et al. (2014). Sox2 acts as a rheostat of epithelial to mesenchymal transition during neural crest development. Front. Physiol. 5:345. doi: 10.3389/fphys. 2014.00345

Mandalos, N., Saridaki, M., Harper, J. L., Kotsoni, A., Yang, P., Economides, A. N., et al. (2012). Application of a novel strategy of engineering conditional alleles to a single exon gene, Sox2. PLoS One 7:e45768. doi: 10.1371/journal.pone. 0045768

Matsuda, S., Kuwako, K., Okano, H. J., Tsutsumi, S., Aburatani, H., Saga, Y., et al. (2012). Sox 21 promotes hippocampal adult neurogenesis via the transcriptional repression of the Hes5 gene. J. Neurosci. 32, 12543-12557. doi: 10. 1523/jneurosci.5803-11.2012

Misra, K., Gui, H., and Matise, M. P. (2008). Proxl regulates a transitory state for interneuron neurogenesis in the spinal cord. Dev. Dyn. 237, 393-402. doi: 10. 1002/dvdy.21422

Oliver, G., Sosa-Pineda, B., Geisendorf, S., Spana, E. P., Doe, C. Q., and Gruss, P. (1993). Prox 1, a prospero-related homeobox gene expressed during mouse development. Mech. Dev. 44, 3-16. doi: 10.1016/0925-4773(93)90012-m

Ouyang, H., Qin, Y., Liu, Y., Xie, Y., and Liu, J. (2013). Prox1 directly interacts with LSD1 and recruits the LSD1/NuRD complex to epigenetically co-repress CYP7A1 transcription. PLoS One 8:e62192. doi: 10.1371/journal.pone.00 62192

Pleasure, S. J., Collins, A. E., and Lowenstein, D. H. (2000). Unique expression patterns of cell fate molecules delineate sequential stages of dentate gyrus development. J. Neurosci. 20, 6095-6105.

Qin, J., Gao, D. M., Jiang, Q. F., Zhou, Q., Kong, Y. Y., Wang, Y., et al. (2004). Prospero-related homeobox (Prox1) is a corepressor of human liver receptor homolog-1 and suppresses the transcription of the cholesterol 7-alpha-hydroxylase gene. Mol. Endocrinol. 18, 2424-2439. doi: 10.1210/me. 2004-0009 
Qin, J., Zhai, J., Hong, R., Shan, S., Kong, Y., Wen, Y., et al. (2009). Prosperorelated homeobox protein (Proxl) inhibits hepatitis B virus replication through repressing multiple cis regulatory elements. J. Gen. Virol. 90, 1246-1255. doi: 10. 1099/vir.0.006007-0

Remboutsika, E., Elkouris, M., Iulianella, A., Andoniadou, C. L., Poulou, M., Mitsiadis, T. A., et al. (2011). Flexibility of neural stem cells. Front. Physiol. 2:16. doi: 10.3389/fphys.2011.00016

Risebro, C. A., Searles, R. G., Melville, A. A., Ehler, E., Jina, N., Shah, S., et al. (2009). Prox 1 maintains muscle structure and growth in the developing heart. Development 136, 495-505. doi: 10.1242/dev.034264

Rubin, A. N., and Kessaris, N. (2013). PROX1: a lineage tracer for cortical interneurons originating in the lateral/caudal ganglionic eminence and preoptic area. PLoS One 8:e77339. doi: 10.1371/journal.pone.0077339

Seri, B., Garcia-Verdugo, J. M., McEwen, B. S., and Alvarez-Buylla, A. (2001). Astrocytes give rise to new neurons in the adult mammalian hippocampus. J. Neurosci. 21, 7153-7160.

Sosa-Pineda, B., Wigle, J. T., and Oliver, G. (2000). Hepatocyte migration during liver development requires Prox1. Nat. Genet. 25, 254-255. doi: 10.1038/76996

Southall, T. D., and Brand, A. H. (2009). Neural stem cell transcriptional networks highlight genes essential for nervous system development. EMBO J. 28, 37993807. doi: 10.1038/emboj.2009.309

Srinivasan, R. S., Geng, X., Yang, Y., Wang, Y., Mukatira, S., Studer, M., et al. (2010). The nuclear hormone receptor Coup-TFII is required for the initiation and early maintenance of Prox1 expression in lymphatic endothelial cells. Genes Dev. 24, 696-707. doi: 10.1101/gad.1859310

Steffensen, K. R., Holter, E., Båvner, A., Nilsson, M., Pelto-Huikko, M., Tomarev, S., et al. (2004). Functional conservation of interactions between a homeodomain cofactor and a mammalian FTZ-F1 homologue. EMBO Rep. 5, 613-619. doi: 10. 1038/sj.embor.7400147

Stein, S., Oosterveer, M. H., Mataki, C., Xu, P., Lemos, V., Havinga, R., et al. (2014). SUMOylation-dependent LRH-1/PROX1 interaction promotes atherosclerosis by decreasing hepatic reverse cholesterol transport. Cell Metab. 20, 603-613. doi: 10.1016/j.cmet.2014.07.023

Steiner, B., Klempin, F., Wang, L., Kott, M., Kettenmann, H., and Kempermann, G. (2006). Type-2 cells as link between glial and neuronal lineage in adult hippocampal neurogenesis. Glia 54, 805-814. doi: 10.1002/glia. 20407

Steiner, B., Zurborg, S., Hörster, H., Fabel, K., and Kempermann, G. (2008). Differential $24 \mathrm{~h}$ responsiveness of Proxl-expressing precursor cells in adult hippocampal neurogenesis to physical activity, environmental enrichment and kainic acid-induced seizures. Neuroscience 154, 521-529. doi: 10.1016/j. neuroscience.2008.04.023

Stergiopoulos, A., and Politis, P. K. (2013). The role of nuclear receptors in controlling the fine balance between proliferation and differentiation of neural stem cells. Arch. Biochem. Biophys. 534, 27-37. doi: 10.1016/j.abb.2012. 09.009

Sugiyama, T., Osumi, N., and Katsuyama, Y. (2014). A novel cell migratory zone in the developing hippocampal formation. J. Comp. Neurol. 522, 3520-3538. doi: $10.1002 / \mathrm{cne} .23621$

Takeda, Y., and Jetten, A. M. (2013). Prospero-related homeobox 1 (Prox1) functions as a novel modulator of retinoic acid-related orphan receptors alphaand gamma-mediated transactivation. Nucleic Acids Res. 41, 6992-7008. doi: 10. 1093/nar/gkt447

Temple, S., and Alvarez-Buylla, A. (1999). Stem cells in the adult mammalian central nervous system. Curr. Opin. Neurobiol. 9, 135-141. doi: 10.1016/s09594388(99)80017-8

Tomarev, S. I., Sundin, O., Banerjee-Basu, S., Duncan, M. K., Yang, J. M., and Piatigorsky, J. (1996). Chicken homeobox gene Prox 1 related to Drosophila prospero is expressed in the developing lens and retina. Dev. Dyn. 206, 354-367. doi: 10.1002/(sici)1097-0177(199608)206:4<354::aid-aja2>3.0.co;2-h
Torii, M., Matsuzaki, F., Osumi, N., Kaibuchi, K., Nakamura, S., Casarosa, S., et al. (1999). Transcription factors Mash-1 and Prox-1 delineate early steps in differentiation of neural stem cells in the developing central nervous system. Development $126,443-456$.

Venere, M., Han, Y. G., Bell, R., Song, J. S., Alvarez-Buylla, A., and Blelloch, R. (2012). Soxl marks an activated neural stem/progenitor cell in the hippocampus. Development 139, 3938-3949. doi: 10.1242/dev.081133

Vessey, J. P., Amadei, G., Burns, S. E., Kiebler, M. A., Kaplan, D. R., and Miller, F. D. (2012). An asymmetrically localized Staufen2-dependent RNA complex regulates maintenance of mammalian neural stem cells. Cell Stem Cell 11, 517528. doi: 10.1016/j.stem.2012.06.010

Wang, L., Jiang, M., Duan, D., Zhao, Z., Ge, L., Teng, X., et al. (2014). Hyperthermia-conditioned OECs serum-free-conditioned medium induce NSC differentiation into neuron more efficiently by the upregulation of HIF-1 alpha and binding activity. Transplantation 97, 1225-1232. doi: 10.1097/tp. 0000000000000118

Wang, J., Kilic, G., Aydin, M., Burke, Z., Oliver, G., and Sosa-Pineda, B. (2005). Proxl activity controls pancreas morphogenesis and participates in the production of "secondary transition" pancreatic endocrine cells. Dev. Biol. 286, 182 194. doi: 10.1016/j.ydbio.2005.07.021

Wang, T. W., Stromberg, G. P., Whitney, J. T., Brower, N. W., Klymkowsky, M. W., and Parent, J. M. (2006). Sox3 expression identifies neural progenitors in persistent neonatal and adult mouse forebrain germinative zones. J. Comp. Neurol. 497, 88-100. doi: 10.1002/cne.20984

Wigle, J. T., Chowdhury, K., Gruss, P., and Oliver, G. (1999). Prox1 function is crucial for mouse lens-fibre elongation. Nat. Genet. 21, 318-322. doi: 10. $1038 / 6844$

Wigle, J. T., Harvey, N., Detmar, M., Lagutina, I., Grosveld, G., Gunn, M. D., et al. (2002). An essential role for Proxl in the induction of the lymphatic endothelial cell phenotype. EMBO J. 21, 1505-1513. doi: 10.1093/emboj/21.7.1505

Wigle, J. T., and Oliver, G. (1999). Proxl function is required for the development of the murine lymphatic system. Cell 98, 769-778. doi: 10.1016/s00928674(00)81511-1

Xu, C., Zhang, Y., Zheng, H., Loh, H. H., and Law, P. Y. (2014). Morphine modulates mouse hippocampal progenitor cell lineages by up-regulating miR181a level. Stem Cells 32, 2961-2972. doi: 10.1002/stem.1774

Yamazaki, T., Yoshimatsu, Y., Morishita, Y., Miyazono, K., and Watabe, T. (2009). COUP-TFII regulates the functions of Prox1 in lymphatic endothelial cells through direct interaction. Genes Cells 14, 425-434. doi: 10.1111/j.1365-2443. 2008.01279.x

Zhou, B., Si, W., Su, Z., Deng, W., Tu, X., and Wang, Q. (2013). Transcriptional activation of the Proxl gene by HIF-lalpha and HIF-2alpha in response to hypoxia. FEBS Lett. 587, 724-731. doi: 10.1016/j.febslet.2013.01.053

Conflict of Interest Statement: The authors declare that the research was conducted in the absence of any commercial or financial relationships that could be construed as a potential conflict of interest.

Received: 15 September 2014; accepted: 16 December 2014; published online: 26 January 2015.

Citation: Stergiopoulos A, Elkouris M and Politis PK (2015) Prospero-related homeobox 1 (Prox1) at the crossroads of diverse pathways during adult neural fate specification. Front. Cell. Neurosci. 8:454. doi: 10.3389/fncel.2014.00454

This article was submitted to the journal Frontiers in Cellular Neuroscience.

Copyright (C) 2015 Stergiopoulos, Elkouris and Politis. This is an open-access article distributed under the terms of the Creative Commons Attribution License (CC BY). The use, distribution and reproduction in other forums is permitted, provided the original author(s) or licensor are credited and that the original publication in this journal is cited, in accordance with accepted academic practice. No use, distribution or reproduction is permitted which does not comply with these terms. 